\title{
Standardized Performance Analysis: An Application to the Texas High Plains
}

\author{
April Clark, Phillip N. Johnson, and \\ James McGrann
}

The Standardized Performance Analysis method was used to complete a whole-farm financial analysis and crop enterprise financial and production analysis of a farming operation in the Texas High Plains for three years of crop production. The Standardized Performance Analysis procedure is described and illustrated for an individual farming operation in addition to a regional level analysis.

D roduction agriculturists have encountered many new challenges as a result of 1 a changing economic environment. Changes in agriculture's economic position stem from several major sources, which include farm policy changes, technology, globalization of markets, and changing financial conditions. With the Federal Agricultural Improvement and Reform (FAIR) Act of 1996, farmers have gained the ability to exercise planting flexibility within their operations, and therefore are able to evaluate new crop enterprises that may lead to increased profits. But, the phasing out of government program payments has reduced the level of income protection that was provided under previous programs. Globalization of agricultural markets has also transferred increased price variability to the farm level, which, in turn, has led agricultural lenders to require more detailed financial information from their clients. Farming operations are now facing greater levels

April Clark is a former research assistant in the Department of Agricultural and Applied Economics, Texas Tech University and is currently employed by Unified Food Service Purchasing Coop.

Plillip Johnson is an associate professor in the Department of Agricultural and Applied Economics, Texas Tech University.

- James McGram is a Professor and Extension Economist (Management) in the Department of Agricultural Economics at Texns AEM University. 
of risk as government programs phase out income protection, lending institutions tighten credit conditions, and global price competition increases.

Farm operators, like other business entities, need accurate production, financial, and marketing information with which to make business decisions. History shows that, while farmers are efficient production managers, they often neglect the financial management and marketing aspects of their farming operations (Klinefelter). As the structure of the agricultural economy changes, business management that encompasses all aspects of the farming operation will be the key to financial survival in the next century (Libbin and Catlett).

\section{Background and Research Objective}

The rash of farm failures of the 1980s revealed the lack of financial information available for farm analysis. Barry, Hopkin, and Baker suggested that following this crisis, demand for information management within the agricultural sector increased. A variety of record-keeping methods were developed, but no uniform method evolved. Without uniform methods of financial analysis, Kohl observed that the agricultural sector lacked standardized data for lenders and producers to make comparisons between farming operations.

The formation of the Farm Financial Standards Council (FFSC) was a response to a need for standardization in the methods used for agricultural financial analysis, which was recognized following the farm financial crisis of the 1980s. The Farm Financial Standards Guidelines (FFSG), which followed the Generally Accepted Accounting Practices (GAAP), with deviations specific to agricultural producers, were adopted in 1990 . These changes were recommended because the methods used to determine, measure, and analyze the financial position and the financial performance of agricultural producers were either totally inadequate or seriously underutilized (Farm Financial Standards Council, p. I-2).

The National Cattlemen's Association, following the FFSC recommendations, requested a management tool that would help improve its members' profitability. The result was the Standardized Performance Analysis (SPA) method of total integrated ranch analysis for cow-calf enterprises. The SPA method provided cow/calf producers with a standardized means of measuring, analyzing, and reporting the performance and profitability of cow-calf enterprises. The cow-calf SPA database of over 600 herds provides "benchmark data" that facilitate comparative analysis (McGrann et al.).

The usefulness of the cow-calf SPA program as a management tool for cow/calf operators led to the development of a similar SPA program for crop production. The new generation of SPA programs allows agricultural producers with crop and livestock enterprises to analyze the production, marketing, and financial position of their operations. The multiple-enterprise SPA program uses actual farm level data to compile accrual-adjusted farm financial statements and complete a whole-farm financial analysis. SPA determines the cost of production for each enterprise, as well as profitability measures for each enterprise and the total operation (McGrann, Michalke, and Stone).

In agricultural business management, determining the unit cost of production, or break-even price, for each enterprise is important because this information allows managers to evaluate enterprise profitability and determine areas in which 
changes could be made to achieve a more efficient operation. Because most farm and ranch operations have more than one crop enterprise and multiple farms within those enterprises, there may exist a different set of cost relationships for each farm or field within the enterprise. Thus, consideration of expenses for each enterprise within the farm or ranch operation allows the farm manager to identify profit and loss centers within the business. With accurate cost of production information, producers may adjust the cost structure of unprofitable enterprises or terminate their production to increase the profitability of the total farming operation.

The Standardized Performance Analysis-Multiple Enterprise (SPA-ME) software program allows for the creation and reconciliation of whole-farm financial statements that provide a basis for enterprise analysis through the allocation of financial statement information to different production enterprises (McGrann, Michalke, and Stone). The financial statements provide information to calculate financial analysis measures for liquidity, solvency, profitability, repayment capacity, and financial efficiency following the FFSG. The SPA-ME program includes a financial and economic cost analysis. Expenses in the financial cost analysis are generated in the accrual-adjusted income statement, and include cash costs, depreciation, and noncash adjustments, such as accounts payable and accrued interest. The economic cost analysis uses the opportunity cost of land and nonreal estate capital to determine the economic cost of production in addition to the financial cost.

Figure 1 presents basic components of the SPA-ME program and their relationships within the framework of the software (McGrann, Michalke, and Stone, p. 9-2). The first element of SPA provides descriptive and production information for the farming operation, including crop share yields and total planted acres. The program then creates a set of total farm financial statements, which contain a beginuing and ending balance sheet, an accrual-adjusted income statement, a cash-flow statement, a statement of owner's equity, and all supporting schedules. This set of financial statements makes up the financial information used in the analysis and is calculated following the FFSG.

The program completes three levels of allocation. The first level of allocation involves individual crop enterprises, which are then broken down into subenterprises representing a specific farm or field. Each level entails the allocation of the total farm balance sheet and income statement using production and descriptive data as a basis for allocation. Other methods of allocation include direct enterprise expense and revenue items on a dollar or per acre percentage basis. Overhead items are allocated at the intermediate level, and then applied to each enterprise at the final level. The allocation of financial information, along with the production information, allows the program to generate financial reports for both crop enterprises and subenterprises. Figure 2 provides a sample of an SPA report from the program.

The SPA-ME program was used to analyze cotton-producing farms in the Texas High Plains (THP) region for the 1995, 1996, and 1997 crop years. These analyses were compiled into a database of results that is made up of 20 producers with approximately 100 subenterprises of irrigated and dryland cotton.

The objectives of this study were to describe the SPA procedure in conducting an individual farm operation and regional database analysis, and to provide an illustration of the application of this procedure to an actual case study farm. 
Figure 1. Components of the SPA-ME program

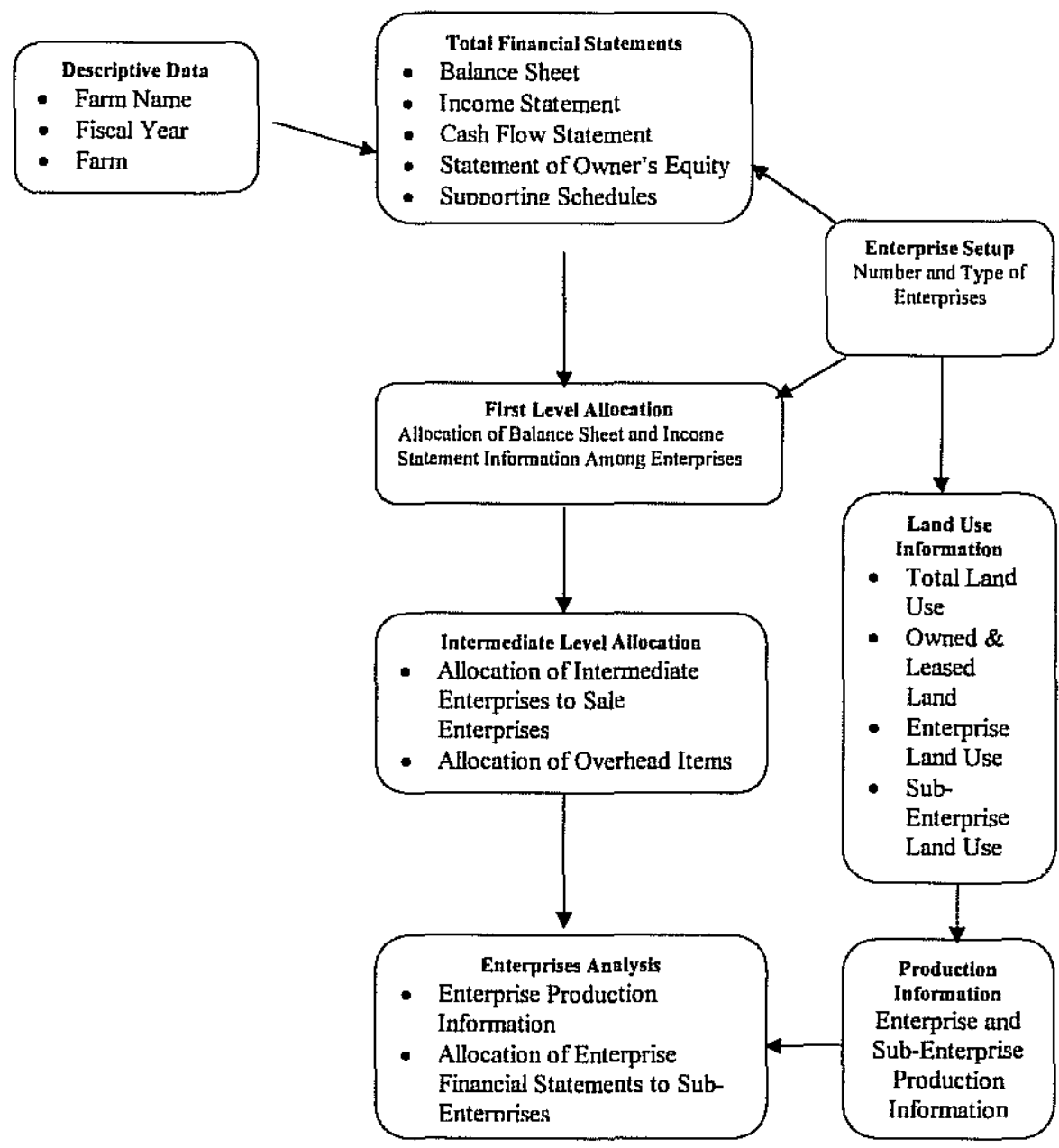

\section{An Application to the Texas High Plains Individual Farming Operation Analysis}

To illustrate the SPA method of farm analysis in providing management information to individual farms, analysis of a farming operation in the THP was conducted for the 1995, 1996, and 1997 crop years. The participating farmer leased land from six individual landlords totaling 828 acres and produced dryland and irrigated cotton during each of the three years analyzed. In 1996 and 1997, grain sorghum was used as a replacement crop for failed cotton. The cotton and grain sorghum crop share rental agreement was $75 \%$ of total production to the tenant and $25 \%$ of total production to the landlord, with certain production input costs being shared by the landlord on a proportional basis.

The farming operation was in the process of expanding through the purchase of additional equipment during the time period of the analysis. Initially, equipment 


\section{Figure 2. SPA Investment, Financial, and Economic Summary}

THP95015

06/01/98 04:00 PM

Dry Cotton Enterprise

Fiscal Year 1995

\section{PRODUCTION SUMMARY}

Primary Product: Cotton Lint Secondary Product: Cotton Seed

Units: Pounds

Units Per Acre: 157.00

Units: Pounds

Units Per Acre: 0.00

\begin{tabular}{|c|c|c|c|c|}
\hline INVESTMENT PER ACRE & \multicolumn{2}{|c|}{$\begin{array}{l}\text { Cost Basis } \\
\$ / \text { Acre }\end{array}$} & \multicolumn{2}{|r|}{$\begin{array}{l}\text { Market Value } \\
\text { \$/Acre }\end{array}$} \\
\hline Total Current Assets & \multirow{2}{*}{\multicolumn{2}{|c|}{$\$ 190$}} & \multicolumn{2}{|r|}{$\$ 190$} \\
\hline Non-Current Assets & & & & \\
\hline Livestock & \multicolumn{2}{|c|}{0} & \multicolumn{2}{|r|}{0} \\
\hline Machinery \& Equipment & \multicolumn{2}{|c|}{49} & \multicolumn{2}{|r|}{49} \\
\hline Real Estate Land \& Improvements & \multicolumn{2}{|c|}{0} & \multicolumn{2}{|r|}{0} \\
\hline Other Non-Current Assets & \multicolumn{2}{|c|}{0} & \multicolumn{2}{|r|}{0} \\
\hline Total Investment & \multicolumn{2}{|c|}{$\$ 240$} & \multicolumn{2}{|r|}{$\$ 240$} \\
\hline Current Enterprise Liabilities & \multicolumn{2}{|c|}{$\$ 54$} & \multicolumn{2}{|r|}{$\$ 54$} \\
\hline Non-Current Enterprise Liabilities & \multicolumn{2}{|c|}{0} & \multicolumn{2}{|r|}{0} \\
\hline Total Enterprise Liabilities & \multicolumn{2}{|c|}{$\$ 54$} & \multicolumn{2}{|r|}{$\$ 54$} \\
\hline Equity to Asset or Percent Equity (\%) & \multicolumn{2}{|c|}{$77.31 \%$} & \multicolumn{2}{|r|}{$77.31 \%$} \\
\hline FINANCIAL AND ECONOMIC & Financial & Econ & & \\
\hline PERFORMANCE & $\$ /$ Acre & $\$ /$ Pounds* & $\$ /$ Acre & $\$ /$ Pounds* \\
\hline $\begin{array}{l}\text { Gross Enterprise Accrual Revenue } \\
\text { Primary Product } \\
\text { Non-Primary Product** } \\
\text { Secondary Product } \\
\end{array}$ & $\begin{array}{r}\$ 107.65 \\
36.31 \\
0.00 \\
\end{array}$ & $\begin{array}{r}\$ 0.686 \\
0.231 \\
0.000 \\
\end{array}$ & $\begin{array}{l}\text { NA } \\
\text { NA } \\
\text { NA }\end{array}$ & $\begin{array}{l}\text { NA } \\
\text { NA } \\
\text { NA }\end{array}$ \\
\hline $\begin{array}{l}\text { Total Cash Costs } \\
\text { Total Non-Cash Costs }\end{array}$ & $\begin{array}{r}\$ 146.18 \\
31.80\end{array}$ & $\begin{array}{r}\$ 0.931 \\
0.203\end{array}$ & $\begin{array}{l}\text { NA } \\
\text { NA }\end{array}$ & $\begin{array}{l}\mathrm{NA} \\
\mathrm{NA}\end{array}$ \\
\hline $\begin{array}{l}\text { Gross Enterprise Accrual Revenue } \\
\text { Total Enterprise Operating Cost } \\
\text { Total Financing Cost \& Economic Return } \\
\text { Total Cost }{ }^{* *} \\
\text { Net Income**. }\end{array}$ & $\begin{array}{r}\$ 143.96 \\
175.85 \\
2.13 \\
177.98 \\
(31.68)\end{array}$ & $\begin{array}{r}\$ 0.917 \\
1.120 \\
0.014 \\
1.134 \\
(0.202)\end{array}$ & $\begin{array}{l}\text { NA } \\
\text { NA } \\
\text { NA } \\
\text { NA } \\
\text { NA }\end{array}$ & $\begin{array}{l}\text { NA } \\
\text { NA } \\
\text { NA } \\
\text { NA } \\
\text { NA }\end{array}$ \\
\hline $\begin{array}{l}\text { Percent Return on Enterprise Assets (ROA } \\
\text { Cost Basis }\end{array}$ & $-12.34 \%$ & Marke & Value & $-12.34 \%$ \\
\hline $\begin{array}{l}\text { UNIT COST OF PRIMARY PRODUCT } \\
\text { Total Non-Primary Product Revenue } \\
\text { Unit Cost of Production }{ }^{* * * *}\end{array}$ & $\begin{array}{r}\$ 36.31 \\
\$ 141.67\end{array}$ & $\begin{array}{l}\$ 0.231 \\
\$ 0.902\end{array}$ & $\begin{array}{l}\mathrm{NA} \\
\mathrm{NA}\end{array}$ & $\begin{array}{l}\mathrm{NA} \\
\mathrm{NA}\end{array}$ \\
\hline
\end{tabular}

- Based on number of units of primary product revenue sold plus inventory adjustments. ** Nonprimary product revenue includes government payments. ** These are pre-tax costs; thus they do not include income tax payments. Withdrawals are included in the cost calculations. *** The net income is pre-tax income, but is not equal to IRS taxable income. **** Adjusted for non-primary product revenue. 
was leased from a relative who was retiring from the farming business, which allowed the farm to remain debt-free in 1995. During 1996 and 1997 debt was acquired to purchase equipment and provide housing for employees. Financial analysis of the operation was based on information submitted from the participating producer. This information was used to construct accrual-adjusted financial. statements, and included beginning and ending fiscal year balance sheets, income statements, IRS tax schedules, loan payment schedules, depreciation schedules, and schedules of the purchase cost of real estate and other capital assets. The total financial position of the farming operation was determined using accrualadjusted financial statements. Income statement analysis of the enterprises within the farming operation was used to determine the unit cost of production for each crop, as well as to determine the impact of government payments and other sources of revenue on the crop enterprises.

Total per acre yields, crop share yield, and planted acres for the dryland and irrigated cotton and grain sorghum enterprises on the case study farm are provided in table 1 . Acreage was shifted from dryland to irrigated cotton from 1995 to 1996 and 1997. The dryland cotton enterprise had increased per acre yields on a planted acre basis across all crop years, with these increases in total yield occurring despite the fact that in 1996 and 1997 approximately 150 and 138 acres of dryland cotton were replanted to grain sorghum, respectively. Irrigated cotton yields were greatest in 1996 at 1,044 pounds per planted acre, about twice that of the yields in the other two years.

Table 1. Dryland and irrigated cotton planted acres and yields for the case study farming operation

\begin{tabular}{|c|c|c|c|}
\hline & $\begin{array}{c}1995 \\
\text { Enterprise } \\
\text { Total } \\
\end{array}$ & $\begin{array}{c}1996 \\
\text { Enterprise } \\
\text { Total } \\
\end{array}$ & $\begin{array}{c}1997 \\
\text { Enterprise } \\
\text { Total } \\
\end{array}$ \\
\hline \multicolumn{4}{|l|}{ Dryland cotton } \\
\hline Total planted acres & 584 & 393 & 381 \\
\hline Per acre yield* $(\mathrm{lb})$ & 209 & 324 & 523 \\
\hline Crop share yield ${ }^{*}(\mathrm{lb})$ & 157 & 243 & 392 \\
\hline \multicolumn{4}{|l|}{ Irrigated cotton } \\
\hline Total planted acres & 244 & 385 & 386 \\
\hline Per acre yield* $(\mathrm{lb})$ & 572 & 1044 & 523 \\
\hline Crop share yield* (lb) & 429 & 783 & 392 \\
\hline \multicolumn{4}{|l|}{ Dryland grain sorghum } \\
\hline Total planted acres & - & 150 & 138 \\
\hline Per acre yield* $(c w t)$ & - & 17.1 & 23.5 \\
\hline Crop share yield* (cwt) & - & 12.8 & 17.6 \\
\hline \multicolumn{4}{|l|}{ Irrigated grain sorghum } \\
\hline Total planted acres & - & - & 50 \\
\hline Per acre yield ${ }^{*}(\mathrm{cwt})$ & - & - & 36.3 \\
\hline Crop share yield* $(\mathrm{cwt})$ & - & - & 27.2 \\
\hline
\end{tabular}

-Based on planted acres. 
Table 2. Summary of farm financial measures for case study farming operation*

\begin{tabular}{lrrr}
\hline & \multicolumn{1}{c}{1995} & \multicolumn{1}{c}{1996} & 1997 \\
\hline Liquidity & & & \\
$\quad$ Current ratio & 3.8 & 3.5 & 4.2 \\
$\quad$ Working capital & $\$ 145,064$ & $\$ 202,117$ & $\$ 206,429$ \\
Solvency & & & \\
$\quad$ Debt/asset ratio & $20.2 \%$ & $32.7 \%$ & $31.3 \%$ \\
$\quad$ Debt/equity ratio & $25.3 \%$ & $48.6 \%$ & $45.6 \%$ \\
Profitability & & & $6.7 \%$ \\
$\quad$ Return on assets & $-0.7 \%$ & $26.7 \%$ & $7.6 \%$ \\
$\quad$ Return on equity & $-1.7 \%$ & $34.0 \%$ & $9.5 \%$ \\
$\quad$ Operating profit margin & $-1.0 \%$ & $29.7 \%$ & $62.6 \%$ \\
Financial efficiency & & & $70.7 \%$ \\
$\quad$ Operating expense ratio & $66.5 \%$ & $46.2 \%$ & \\
Asset turnover ratio & $66.4 \%$ & $90.1 \%$ & \\
\hline
\end{tabular}

*Based on year-end financial statements.

Table 2 presents the results of the whole-farm financial analysis, including liquidity, solvency, profitability, and financial efficiency. Liquidity measures the ability to meet current financial obligations as they come due in the ordinary course of business and is described by the current ratio and working capital. Solvency measures the extent that borrowed capital is being used in the business and provides an indication of the ability to remain viable under financial adversity. Solvency is measured by the debt-to-asset and debt-to-equity ratios. The debt-toequity ratio is often referred to as the leverage ratio, which shows the extent to which debt capital is being combined with equity capital. Profitability measures the extent to which a business generates a profit from investment in productive resources. Return on assets, return on equity, and operating profit margin measure profitability. Financial efficiency measures the intensity of asset use to generate gross revenues as measured by the operating expense ratio and asset turnover ratio (Farm Financial Standards Council).

Results of the whole-farm analysis for the case study farm indicate that the farm has a strong liquidity position. The current ratio for the operation was greater than 3:1 for all three years. The amount of working capital in the operation also increased over the three years of the analysis, with the level of working capital always greater than $70 \%$ of total cash operating expenses. The solvency of the operation as measured by the debt-to-asset and debt-to-equity ratios shows an increasing use of debt, yet because the operation was in an expansion mode, increases in debt levels were expected. The debt-to-asset ratio for the operation increased from $20.2 \%$ at the end of 1995 to $31.3 \%$ at the end of the 1997 crop year, primarily because of the acquisition of additional equipment using debt to finance a portion of the purchases. The debt-to-equity ratio for the operation showed an increase across the three years from $25.3 \%$ to $45.6 \%$. However, solvency values of the operation are well within accepted ranges for both measures. 
Profitability measures include the return on assets (ROA), return on equity (ROE), and operating profit margin. Comparing the ROA to the ROE for all three years shows that debt was used profitably by the operation in 1996 and 1997, but not in 1995. The ROE being less than the ROA in 1995 indicates that the operation paid more in interest expense to borrow funds than it earned by investing the funds in the operation. The reason for this unprofitable relationship, and the negative values of both the ROA and the ROE, was the operation's negative net income in the 1995 crop year. The operating profit margin ratio in 1995 was also negative because of the negative net income in that year. Comparing the operating profit margin ratios for the three years of analysis shows that every dollar of gross farm revenue earned by the operation led to negative returns to net farm capital in 1995. However, this situation improved in 1996 and 1997, as every dollar of gross farm income earned returned $\$ 0.30$ and $\$ 0.10$, respectively, to net farm capital. Despite the fact that 1996 was a more profitable year than 1997, the returns in both of these crop years were acceptable because debt was used profitably by the operation and returns to net farm capital were positive. Financial efficiency for the case study farm was very good across all years of the analysis. Operating expense ratios were consistently under $70 \%$, and below $50 \%$ in 1996. In addition, this operation was able to exhibit high asset turnover ratios across all years.

Considering the three-year performance of the total farming operation, the case study farm is considered to be financially viable. The SPA analysis shows that the operation has been able to expand through the acquisition of machinery and equipment yet maintain strong liquidity and profitability. The use of the SPA program to analyze an operation over a period of years allows the measurement of financial progress over time and identification of trends within the business.

\section{Enterprise Analysis}

Most farming operations have more than one enterprise. The SPA program provides the ability to analyze specific enterprises within an operation through the allocation of direct expenses, overhead expenses, revenues, and capital investment to the enterprise level. The enterprise analysis calculates enterprise costs of production on per acre and per unit bases, in addition to measuring profitability and financial performance at the enterprise level. The enterprise analysis for the case study farm focuses on dryland and irrigated cotton. The grain sorghum enterprise was included in the analysis, but was unprofitable in all cases when used as a replacement crop for failed cotton.

The SPA program accounts for owner labor and management expense (family living withdrawals) as a production cost; therefore it is included in the unit cost of production. Family living withdrawals should be at a level equivalent to the salary required to hire a non-family member to provide an equivalent service. Withdrawals in excess of this should be considered as capital distributions. Accounting for owner labor and management expense is important in order to allow for comparisons between different types of business structures, such as sole proprietorships and corporations. Under a corporate structure, owner labor and management is generally paid as a salary, which is a payroll expense. Therefore, to standardize the calculation of production costs, family living withdrawals should be included in all analyses as the cost of labor and management. 
Table 3. Dryland cotton income statement comparison for the case study farming operation

\begin{tabular}{|c|c|c|c|}
\hline & \multicolumn{3}{|c|}{$\$ /$ Acre } \\
\hline & 1995 & 1996 & 1997 \\
\hline Gross accrual revenue & 143.96 & 204.98 & 366.51 \\
\hline Primary product sales & 107.65 & 159.63 & 225.04 \\
\hline Government payments & 10.23 & 20.14 & 18.72 \\
\hline Crop insurance proceeds & 7.14 & 12.50 & 17.55 \\
\hline Other revenue* & 18.94 & 12.71 & 105.20 \\
\hline Total operating cost & 177.98 & 175.14 & 304.04 \\
\hline Cash operating expense & 120.44 & 115.27 & 203.54 \\
\hline Depreciation & 33.81 & 41.94 & 51.76 \\
\hline Non-cash costs** & -2.01 & -0.14 & 0.72 \\
\hline Interest expense & 2.13 & 3.56 & 6.79 \\
\hline Owner labor \& mgmt. & 23.61 & 14.51 & 41.23 \\
\hline Net income & -34.02 & 29.84 & 62.47 \\
\hline Unit costs of production ${ }^{* * *}(\$ / \mathrm{lb})$ & 0.90 & 0.53 & 0.42 \\
\hline Primary product price $(\mathrm{Q} / \mathrm{lb})$ & 0.69 & 0.66 & 0.57 \\
\hline
\end{tabular}

*Other revenue includes cooperative distributions, interest income, and hedging income.

*"Includes only accrual adjustments.

"**Adjusted for non-primary product revenue.

Deducting non-primary product revenue from the total operating costs and dividing by the quantity of production calculate the unit cost of production of the primary product. The unit cost of production represents the price of the primary product that would result in a breakeven being achieved and can be compared to unit prices received to evaluate competitiveness of an enterprise (McGrann, Michalke, and Stone). The unit cost of production also provides useful information in evaluating marketing alternatives.

Table 3 presents the income statement information for the case study farm for dryland cotton. The net income per acre indicates that 1995 was not a profitable year for the dryland cotton enterprise, with net returns of $-\$ 34.02$ per acre. Yields on the dryland cotton in 1995 were low because of dry weather conditions, which contributed to the unprofitable outcome for this enterprise. However, the profitability of dryland cotton improved in 1996 and 1997, with net returns of $\$ 29.84$ and $\$ 62.47$ per acre, respectively. The unit cost of production for the dryland cotton enterprise decreased dramatically across the three years from $\$ 0.90$ per pound in 1995 to $\$ 0.42$ per pound in 1997 . This decrease in unit cost of production was the result of higher per acre yields, especially in 1997, which increased net returns per acre despite lower cotton lint prices. Primary product sales indicate the price received for cotton lint production was $\$ 0.69$ per pound in 1995 and $\$ 0.66$ per pound in 1996, but declined in 1997 to $\$ 0.57$ per pound. Furthermore, comparing the unit cost of production to the primary product price shows that 1995 was the only year in which primary product price was less than the unit cost of 
Table 4. Irrigated cotton income statement comparison for the case study farming operation

\begin{tabular}{|c|c|c|c|}
\hline & \multicolumn{3}{|c|}{$\$$ /Acre } \\
\hline & 1995 & 1996 & 1997 \\
\hline Gross accrual revenue & 344.88 & 568.39 & 366.91 \\
\hline Primary product sales & 309.35 & 516.11 & 231.19 \\
\hline Government payments & 10.01 & 13.71 & 19.23 \\
\hline Crop insurance proceeds & 6.99 & 0.00 & 8.53 \\
\hline Other revenue* & 18.53 & 38.57 & 107.96 \\
\hline Total operating cost & 276.32 & 335.00 & 331.33 \\
\hline Cash operating expense & 176.72 & 215.44 & 230.52 \\
\hline Depreciation & 33.09 & 40.83 & 51.70 \\
\hline Non-cash costs** & -1.97 & -2.24 & 0.74 \\
\hline Interest expense & 2.08 & 15.96 & 6.70 \\
\hline Owner labor \& mgmt. & 66.40 & 65.01 & 41.67 \\
\hline Net income & 68.56 & 233.39 & 35.58 \\
\hline Unit costs of production ${ }^{* * *}(\$ / \mathrm{lb})$ & 0.57 & 0.36 & 0.50 \\
\hline Primary product price $(\$ / \mathrm{lb})$ & 0.72 & 0.66 & 0.59 \\
\hline
\end{tabular}

*Other revenue includes cooperative distributions, interest income, and hedging income.

**Includes only accrual adjustments.

${ }^{* * *}$ Adjusted for non-primary product revenue.

production. Government payments, crop insurance proceeds, and other revenue accounted for $22.2 \%, 22.1 \%$, and $38.6 \%$ of total revenue in 1995,1996 , and 1997 , respectively, and exceeded net returns for all years. The large increase in other revenue and cash operating expenses in 1997 was due to the fact that 1997 was the only year in which cottonseed revenue was accounted for as a revenue item rather than being applied to pay ginning expenses and ginning expense was accounted for as an expense item. The allocation of cottonseed revenues as a revenue item was done to more accurately state the enterprise revenues and expenses.

The income statement information for irrigated cotton presented in table 4 indicates that net returns were positive in all years, with the highest net income of $\$ 233.39$ per acre in 1996. Like the dryland cotton enterprise, the price received for cotton lint declined across the three-year period. Comparing the unit cost of production to the primary product price shows that the irrigated cotton enterprise was profitable in all three years when accounting for only primary product revenue. Government payments, crop insurance proceeds, and other revenue accounted for $10.3 \%, 9.2 \%$, and $37.0 \%$ of total revenue in 1995,1996 , and 1997, respectively. The increase in other revenue across the three years of analysis is once again due to cottonseed revenue being accounted for separately from ginning charges in 1997. As with the dryland cotton enterprise, depreciation expense increased as the operation expanded with the purchase of new equipment.

Balance sheet and profitability measures for the dryland and irrigated cotton crops are provided in tables 5 and 6 , respectively. The total investment for both 
Table 5. Dryland cotton balance sheet and profitability comparison for the case study farming operation

\begin{tabular}{lrrr}
\hline \hline & \multicolumn{3}{c}{$\$ /$ Acre } \\
\cline { 2 - 4 } & \multicolumn{1}{c}{$\mathbf{1 9 9 5}$} & $\mathbf{1 9 9 6}$ & $\mathbf{1 9 9 7}$ \\
\hline Total investment & 239 & 275 & 444 \\
Current assets & 190 & 155 & 336 \\
Maclinery/equipment & 49 & 120 & 102 \\
Other non-current assets & 0 & 0 & 6 \\
Total liabilities & 54 & 76 & 167 \\
Current liabilities & 54 & 62 & 101 \\
Non-current liabilities & 0 & 14 & 66 \\
Total owner equity & 185 & 199 & 277 \\
Debt/asset ratio & $22.6 \%$ & $27.6 \%$ & $37.6 \%$ \\
Debt/equity ratio & $29.2 \%$ & $38.2 \%$ & $60.3 \%$ \\
Return on assets & $-13.3 \%$ & $12.1 \%$ & $15.6 \%$ \\
Return on equity & $-18.4 \%$ & $15.0 \%$ & $22.6 \%$ \\
\hline \hline
\end{tabular}

Note: Only cost basis values are shown.

dryland and irrigated cotton enterprises increased over the three years of the analysis as the operation has grown. In addition, liabilities of the operation have also increased across the three years of the analysis as the operation increased its debt levels in order to expand. Increases in debt levels are also illustrated by the debt-to-equity ratio, which increased on both enterprises from 1995 to 1997. Debt was used profitably in the dryland cotton enterprise in 1996 and 1997, because the ROA was greater than the ROE. Debt was used profitably in the irrigated cotton enterprise all three years.

The income statement information for the grain sorghum enterprises for 1996 and 1997 is provided in table 7. In all three cases, grain sorghum was an unprofitable replacement crop for failed cotton. The unit cost of production was greater than primary product price in each case, indicating the operation was not covering the variable costs of production to produce the crop. Therefore, considering the income statement performance, the operation would have been more profitable not planting the grain sorghum replacement crop for the failed cotton.

Overall, the performance of the dryland and irrigated cotton enterprises on the case study farm was acceptable. The 1995 crop year exhibited poor net returns, which were due to lower than average yields across the THP in that year for dryland crops. Net returns increased to profitable levels in 1996 for both of the dryland and irrigated cotton enterprises. The profits for 1997 were lower than the 1996 returns, as yields and prices were lower in 1997 than the previous year. However, considering the three-year performance of the dryland and irrigated cotton enterprises, unit cost of production was lower than primary product price in all years, with the exception of the dryland cotton crop in 1995. 
Table 6. Irrigated cotton balance sheet and profitability comparison for the case study farming operation

\begin{tabular}{lrrr}
\hline \hline & \multicolumn{3}{c}{$\$ /$ Acre } \\
\cline { 2 - 4 } & $\mathbf{1 9 9 5}$ & 1996 & $\mathbf{1 9 9 7}$ \\
\hline Total investment & 466 & 563 & 577 \\
$\quad$ Current assets & 418 & 435 & 340 \\
Machinery/equipment & 48 & 128 & 231 \\
Other non-current assets & 0 & 0 & 6 \\
Total liabilities & 88 & 174 & 168 \\
$\quad$ Current liabilities & 88 & 113 & 102 \\
Non-current liabilities & 0 & 61 & 66 \\
Total owner equity & 378 & 389 & 409 \\
Debt/asset ratio & $18.9 \%$ & $30.9 \%$ & $29.1 \%$ \\
Debt/equity ratio & $23.3 \%$ & $44.7 \%$ & $41.1 \%$ \\
Return on assets & $15.2 \%$ & $44.3 \%$ & $7.3 \%$ \\
Return on equity & $18.1 \%$ & $60.0 \%$ & $8.7 \%$ \\
\hline \hline
\end{tabular}

Note: Only cost basis values are shown.

Table 7. Grain sorghum income statement comparison for the case study farming operation

\begin{tabular}{|c|c|c|c|}
\hline & \multicolumn{3}{|c|}{ \$/Acre } \\
\hline & 1995 & 1996 & 1997 \\
\hline Gross accrual revenue & 57.44 & 80.49 & 122.25 \\
\hline Primary product sales & 53.18 & 77.51 & 118.49 \\
\hline Government payments & 3.17 & 0.00 & 0.00 \\
\hline Crop insurance proceeds & 0.00 & 0.00 & 0.00 \\
\hline Other revenue* & 1.09 & 2.98 & 3.76 \\
\hline Total operating cost & 149.04 & 147.93 & 217.99 \\
\hline Cash operating expense & 103.29 & 81.25 & 123.51 \\
\hline Depreciation & 41.00 & 37.69 & 34.68 \\
\hline Non-cash costs $* *$ & -3.17 & 0.28 & 0.96 \\
\hline Interest expense & 1.56 & 7.03 & 6.46 \\
\hline Owner labor \& mgmt. & 6.36 & 21.68 & 52.38 \\
\hline Net income & -91.60 & -67.44 & -95.74 \\
\hline Unit costs of production ${ }^{* * *}(\$ / c w t)$ & 11.27 & 8.22 & 7.86 \\
\hline Primary product price $(\$ / \mathrm{cw} t)$ & 4.14 & 4.40 & 4.35 \\
\hline
\end{tabular}

*Other revenue includes cooperative distributions, interest income, and hedging income.

**Includes only accrual adjustments.

${ }^{* * *}$ Adjusted for non-primary product revenue. 


\section{Regional Analysis}

The use of SPA to compile a database of actual farm level financial performance, cost of production, and profitability of enterprises for the region provides useful information to farmers, agricultural credit providers, and commodity groups. A database of farm-level analyses provides a basis of comparison for individual farm operations to gauge financial and production performance. Database results are available from SPA analysis in the THP for the 1995, 1996, and 1997 crop years. The 1995 database contains SPA results for 23 dryland cotton observations from 10 producers and 31 irrigated cotton observations from 12 producers. The 1996 database contains SPA results for 22 dryland cotton observations from 7 producers and 43 irrigated cotton observations from 13 producers. The 1997 database contains SPA results for 30 dryland cotton observations from 10 producers and 48 irrigated cotton observations from 12 producers. An observation consists of an enterprise analysis for a specific farm or field; therefore producers could have multiple observations from a single farming operation. The regional database results are weighted averages of the observations based on planted acres. Results are reported for dryland and irrigated cotton enterprises rented on a crop share basis only, as there were not sufficient observations to accurately report results for other field crops or owner-operated observations.

Table 8. Income statement characteristics from SPA analysis in the Texas High Plains for crop share dryland cotton enterprises for $1995-1997$

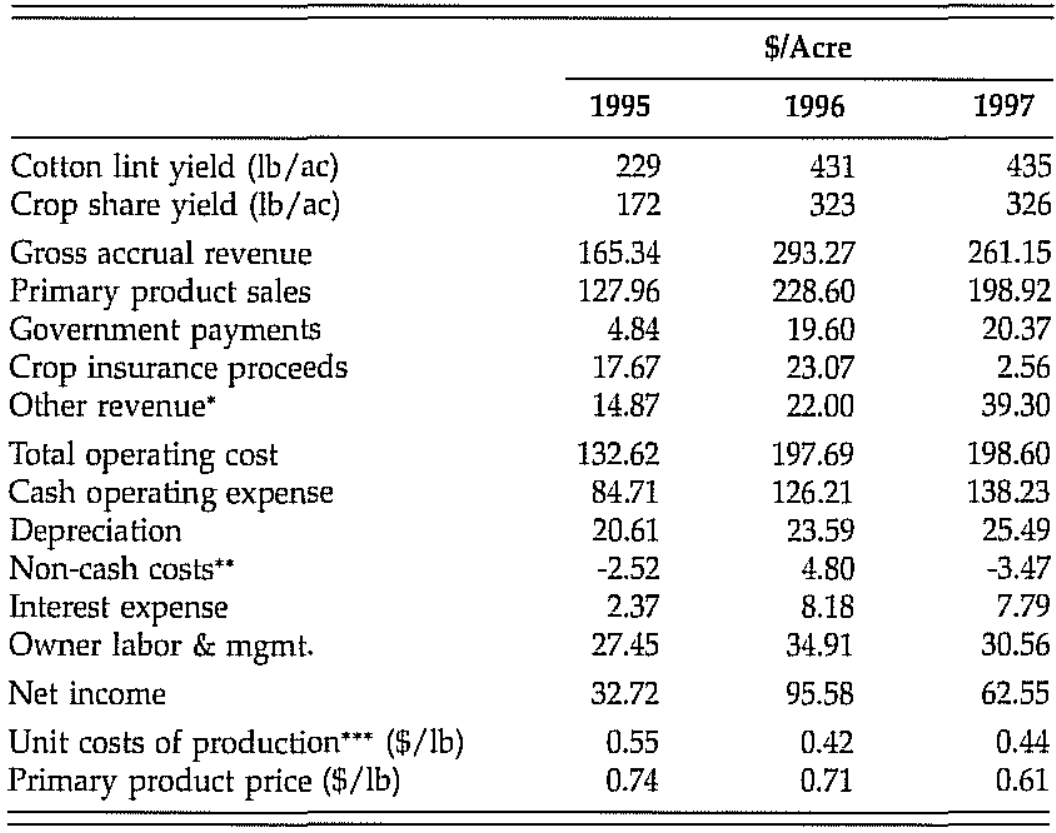

* Other revenue includes cooperative distributions, interest income, and hedging income.

**Includes only accrual adjustments.

**Adjusted for non-primary product revenue. 
Table 9. Income statement characteristics from SPA analysis in the Texas High Plains for crop share irrigated cotton enterprises for 1995-1997

\begin{tabular}{|c|c|c|c|}
\hline & \multicolumn{3}{|c|}{$\$ /$ Acre } \\
\hline & 1995 & 1996 & 1997 \\
\hline Cotton lint yield (lb/ac) & 520 & 601 & 520 \\
\hline Crop share yield ( $\mathrm{b} / \mathrm{ac})$ & 390 & 451 & 390 \\
\hline Gross accrual revenue & 311.62 & 359.89 & 303.82 \\
\hline Primary product sales & 261.49 & 301.11 & 226.12 \\
\hline Government payments & 9.89 & 27.30 & 28.40 \\
\hline Crop insurance proceeds & 5.76 & 7.65 & 6.41 \\
\hline Other revenue* & 34.48 & 23.66 & 42.84 \\
\hline Total operating cost & 302.79 & 252.00 & 288.74 \\
\hline Cash operating expense & 204.95 & 175.33 & 221.25 \\
\hline Depreciation & 30.44 & 33.90 & 30.98 \\
\hline Non-cash costs ${ }^{* *}$ & 2.51 & -2.92 & -3.60 \\
\hline Interest expense & 14.97 & 12.72 & 14.06 \\
\hline Owner labor \& mgmt. & 49.92 & 32.97 & 26.05 \\
\hline Net income & 8.83 & 107.89 & 15.08 \\
\hline Unit costs of production ${ }^{* * *}(\$ / l b)$ & 0.65 & 0.43 & 0.54 \\
\hline Primary product price $(\$ / \mathrm{lb})$ & 0.67 & 0.67 & 0.58 \\
\hline
\end{tabular}

*Other revenue includes cooperative distributions, interest income, and hedging income.

${ }^{*}$ Includes only accrual adjustments.

***Adjusted for non-primary product revenue.

Regional income statement characteristics for dryland and irrigated cotton are shown in tables 8 and 9, respectively. Returns for dryland and irrigated cotton production in the region varied over the three years, with the lowest net incomes in 1995. Profitability increased for both dryland and irrigated cotton production in 1996 and 1997. The unit cost of production for both dryland and irrigated cotton was below the primary product price for all years, indicating that THP cotton producers were competitive within the cotton industry. The unit cost of production for dryland cotton averaged less than irrigated cotton, $\$ 0.47 / \mathrm{lb}$ and $\$ 0.54 / \mathrm{lb}$, respectively. Dryland cotton production was more profitable on a per acre basis than irrigated cotton in 1995 and 1997. Total operating cost per acre for irrigated cotton production was $59 \%$ greater than dryland cotton production, while cash operating cost for irrigated cotton averaged $72 \%$ per acre more than dryland production.

Owner labor and management expense (family living withdrawals) made up from $9 \%$ to $16 \%$ of total operating cost for dryland cotton, and $15 \%$ to $21 \%$ of total operating cost for irrigated cotton. The percentage of gross accrual revenue derived from non-primary product revenue was about $23 \%$ for dryland cotton across all years. Non-primary product revenue for irrigated cotton represented $16 \%$ of gross accrual revenue for both 1995 and 1996, and increased to $26 \%$ in 1997, 
Table 10. Balance sheet and profitability measures from SPA analysis in the Texas High Plains for crop share dryland cotton enterprises for 1995-1997

\begin{tabular}{lrrr}
\hline \hline & 1995 & $\mathbf{1 9 9 6}$ & $\mathbf{1 9 9 7}$ \\
\hline Total investment (\$/ac) & 319 & 319 & 368 \\
Total liabilities (\$/ac) & 144 & 90 & 163 \\
Total owner equity (\$/ac) & 175 & 229 & 205 \\
Debt/asset ratio (\%) & 45.2 & 28.2 & 44.4 \\
Debt/equity ratio (\%) & 82.5 & 39.3 & 79.9 \\
Return on assets (\%) & 11.0 & 32.5 & 19.1 \\
Return on equity (\%) & 18.7 & 41.7 & 30.6 \\
\hline \hline
\end{tabular}

Note: Cost basis valuation.

representing an important source of revenues. For the participating producers in the THP, cooperative distributions, which are reported as other revenue, made up approximately $7 \%$ to $15 \%$ of gross accrual revenues for dryland and irrigated cotton across all years. Government payments represented approximately $7 \%$ to $9 \%$ of gross accrual revenues for both dryland and irrigated cotton in 1996 and 1997, respectively. Government payments received in 1995 were reduced due to the repayment of overpayments received in 1994.

Tables 10 and 11 show the balance sheet and profitability measures for dryland and irrigated cotton enterprises, respectively. The results show an increase in owner's equity for both dryland and irrigated cotton from 1995 to 1996, and irrigated cotton from 1996 to 1997. Debt levels decreased for dryland cotton from 1995 to 1996 with a decrease in both the debt-to-asset and debt-to-equity ratios. This result may be due to a profitable year for dryland producers in 1996, indicating that profits may have been used to reduce debt levels. Profitability in 1996 as measured by ROA and ROE was very good for both dryland and irrigated producers, with a ROA for dryland and irrigated cotton of $32.5 \%$ and $21.8 \%$, respectively. The large increase in ROA and ROE in 1996 may be explained by the increased yields compared to 1995. In 1997, ROA and ROE declined for both dryland and irrigated cotton production, yet remained at favorable levels for dryland cotton production, while returning to 1995 levels for irrigated cotton production.

Table 12 gives the average farm financial measures for the farms represented in the regional database. The results show declining liquidity as shown by the current ratio declining from 4.3 in 1995 to 1.8 in 1997. Solvency measures indicated a consistent capital structure, with debt-to-asset ratios ranging from $36 \%$ to $43 \%$, and debt-to-equity ratios ranging from $60 \%$ to $114 \%$. Return on assets and return on equity indicated the profitable use of debt, given ROE was greater than ROA for all years.

The comparison of an individual farm's SPA analysis to the regional database allows a farm manager to gauge financial performance compared to similar farms in the region and to possibly identify areas within their operation that may need attention. The income statement information for the case study farm and the THP 
Table 11. Balance sheet and profitability measures from SPA analysis in the Texas High Plains for crop share irrigated cotton enterprises for 1995-1997

\begin{tabular}{lrcr}
\hline \hline & 1995 & $\mathbf{1 9 9 6}$ & $\mathbf{1 9 9 7}$ \\
\hline Total investment (\$/ac) & 381 & 553 & 581 \\
Total liabilities (\$/ac) & 218 & 253 & 237 \\
Total owner equity (\$/ac) & 162 & 300 & 344 \\
Debt/asset ratio (\%) & 57.4 & 45.8 & 40.7 \\
Debt/equity ratio (\%) & 134.9 & 84.3 & 68.8 \\
Return on assets (\%) & 6.2 & 21.8 & 5.0 \\
Return on equity (\%) & 5.4 & 36.0 & 4.4 \\
\hline \hline
\end{tabular}

Note: Cost basis valuation.

Table 12. Summary of farm financial measures for regional database ${ }^{*}$

\begin{tabular}{lrrr}
\hline & 1995 & 1996 & 1997 \\
\hline Liquidity & & & \\
$\quad$ Current ratio & 4.3 & 2.7 & 1.8 \\
$\quad$ Working capital & $\$ 137,624$ & $\$ 32,030$ & $\$ 105,263$ \\
Solvency & & & \\
$\quad$ Debt/asset ratio & $36.6 \%$ & $43.0 \%$ & $36.3 \%$ \\
$\quad$ Debt/equity ratio & $70.7 \%$ & $113.6 \%$ & $60.1 \%$ \\
Profitability & $14.8 \%$ & $23.2 \%$ & $15.9 \%$ \\
$\quad$ Return on assets & $24.3 \%$ & $56.6 \%$ & $22.9 \%$ \\
$\quad$ Return on equity & $4.2 \%$ & $28.5 \%$ & $10.7 \%$ \\
$\quad$ Operating profit margin & & & \\
Financial efficiency & $63.6 \%$ & $54.5 \%$ & $73.2 \%$ \\
$\quad$ Operating expense ratio & $53.2 \%$ & $45.7 \%$ & $57.8 \%$ \\
$\quad$ Asset turnover ratio & & & \\
\hline \hline
\end{tabular}

*Based on year-end financial statements.

regional database are given in tables $3,4,8$, and 9 . A comparison shows that the case study farm was less profitable in the production of dryland cotton than the regional results for both 1995 and 1996, and equal to the region in 1997. The unit cost of production of dryland cotton for the case study farm was greater than the region for 1995 and 1996 and about the same for 1997. However, dryland cotton unit cost of production for the case study farm for 1996 and 1997 averaged $\$ 0.475 / \mathrm{lb}$ compared to the three-year average for the region of $\$ 0.47 / \mathrm{lb}$. The case study farm's dryland cotton yields generally were comparable to the regional database, while cash operating costs were higher in two of the three years. The price received for cotton lint by the case study farm for dryland cotton aver- 
aged $\$ 0.64 / \mathrm{lb}$ compared to the regional database average dryland cotton price of $\$ 0.687 / \mathrm{lb}$.

The case study farm was more profitable than the region in the production of irrigated cotton. Unit cost of production of irrigated cotton for the case study farm averaged $\$ 0.477 / \mathrm{lb}$, which compares favorably with the regional unit cost of production of $\$ 0.54 / \mathrm{lb}$. The case study farm's irrigated cotton yields averaged $713 \mathrm{lb} /$ acre compared to the regional database average irrigated yields of $547 \mathrm{lb} /$ acre. Cash operating cost per acre and cotton price were generally comparable between the case study farm and the region. Depreciation expense per acre was higher for the case study farm compared to the regional database for both dryland and irrigated cotton due primarily to the acquisition of equipment by the case study farm during the period of analysis.

Enterprise balance sheet and profitability information for the case study farm and THP regional database are shown in tables 5,6,10, and 11. A comparison shows that the case study farm has higher owner's equity and lower debt per acre than the regional database with debt-to-asset and debt-to-equity ratios lower for the case study farm in all cases. Profitability measures again show that the case study farm is more profitable in the production of irrigated cotton compared to the regional database and less profitable in dryland cotton production.

A comparison of farm financial measures shown in tables 2 and 12 for the case study farm and the regional database show that the case study farm has had increasing liquidity over the three years while farms in the regional database have had declining liquidity. The case study farm has a lower level of debt compared to the region; however, the case study farm has been increasing its debt over time. The case study farm has exhibited lower profitability compared to the region; however, the case study farm's financial efficiency compares favorably with the region.

\section{Study Conclusions}

The use of a standardized method of farm analysis has several underlying management implications. The SPA method provides accurate information regarding each aspect of the farming operation and allows producers to analyze the financial performance of their total farming operation, crop enterprises within their operation, and individual farm subenterprises within the crop enterprises, thereby providing a useful financial management tool. This study shows the practical use of comparative analysis for a farming operation across crop years. In this study, the case study farmer was able to determine that his grain sorghum enterprise was always unprofitable and impacted his total profits in a negative fashion. Therefore, in the future he may change his practice of replacing failed cotton with grain sorghum.

In addition to the analysis of the case study farm, other farming operations in the THP were analyzed using the SPA method. These results were compiled into a database that provides production and financial information regarding the cotton production sector in this region. The case study farm's profitability for irrigated cotton production was greater than the region, while dryland cotton production profitability was less than the region. The lower profitability of dryland cotton production on the case study farm was related to higher production costs and 
lower cotton price received compared to the region. The case study farmer should look at specific cost items in his dryland cotton production system to determine areas where costs could be reduced. The SPA information is useful to farmers, agricultural credit providers, and commodity groups to assess the competitiveness of the region in cotton production and providing accurate cost of production information.

\section{Acknowledgments}

The authors wish to thank Blake Bennett, R. Terry Ervin, Don Ethridge, and Sukant Misra, Texas Tech University, and M. Darren Hudson, Mississippi State University, for their comments. Cotton, Incorporated and the Texas State Support Committee provided funding for the Standardized Performance Analysis research program.

\section{References}

Barry, P.J., J.A. Hopkin, and C.B. Baker. Financial Mantgenent in Agriculture. Danville, IL: The Interstate Printers and Publishers, Inc., 1988.

Farm Financial Standards Council. Financial Guidelines For Agriculturnl Producers II. Naperville, $\mathrm{L}$, December 1997.

Klinefelter, D. Farm Mantagement Handbook: Characteristics of Farmers Who Hnve Failed. Texas Agricultural Extension Service, Texas A\&M University, 1988.

Kohl, D.M. Weighing the Varinbles: A Guide to Ag Crtdit Mantgement. Washington, DC: American Bankers Association, 1992.

Libbin, J.D., and L.B. Catlett. Form and Ranch Financial Retcords. New York, NY: Macmillan Publishing Company, 1987.

McGrann, J.M., N. Michalke, and J.A. Stone. Standardized Peyformance Analysis (SPA) Cotton and Crop SPA Handbook: Standardized Performance Analysis-Multiple Enterprise (SPA-ME) Software Instructions. Texas Agricultural Extension, Texas A\&M University, Department of Agricultural Economics, 1996.

McGrann, J.M., J. Parker, S. Neibergs, L. Falconer, E.D. Hamilton, G. Clary, R. Sharp, N. Bludau, and D.A. Klinefelter. Integrated Resource Management-Standardized Performance Annlysis (SPA): Commercinl Cow - -Cnlf SPA Handbook. Texas Agricultural Extension Service, Texas A\&M University, Department of Agricultural Economics, 1994. 